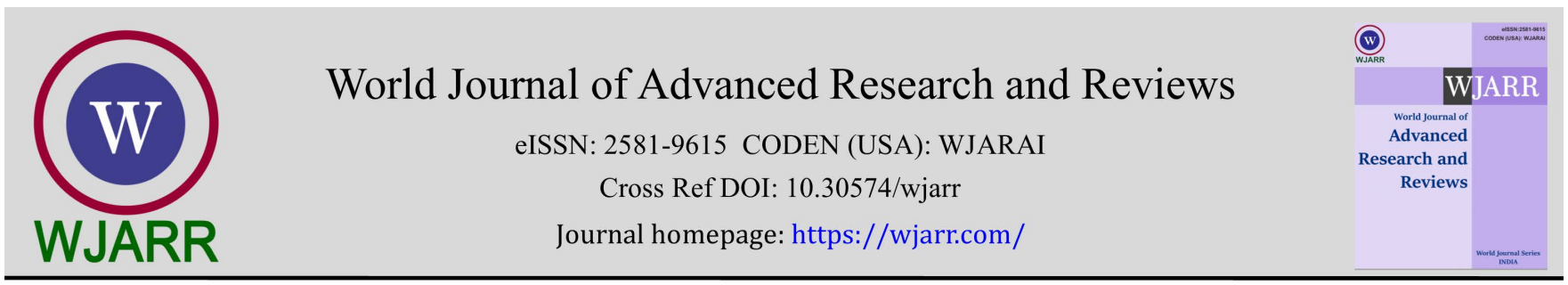

(RESEARCH ARTICLE)

\title{
Specific identification and antibiotic-sensitivity of Acinetobacter strains
}

\author{
Davitashvili Magda * Zuroshvili Lamara, Margalitashvili Darejan and Azikuri Gela \\ Iakob Gogebashvili Telavi State University, 1, Kartuli Universiteti str., Telavi, 2200, Georgia.
}

World Journal of Advanced Research and Reviews, 2021, 11(03), 424-428

Publication history: Received on 19 August 2021; revised on 26 September 2021; accepted on 28 September 2021

Article DOI: https://doi.org/10.30574/wjarr.2021.11.3.0473

\begin{abstract}
80 Acinetobacter strains were studied. Their differentiation according to the specific belonging showed that 55 strains belonged to A. calcoaceticus var. anitratum species and 25 strains to A. calcoaceticus var. lwoffi. It was established that Acinetobacter strains are multi dry resistant. In particular they showed $100 \%$ resistance to ampicillin, carbenicillin, erythromycin, methicillin, oxacillin, tetracycline, oleandomycin, streptomycin, rondomycin, linkomycin. According to the obtained data claphoran and phortum are the most effective.
\end{abstract}

Keywords: Bacteriophage; Biological properties; Pyocyanic bacteria; Sewage waters; Diagnostics.

\section{Introduction}

Internal infections in hospitals are one of the major problems in modern medicine. As a result of the decline in the body's resistance to the underlying disease, which is preceded by antibiotic- and immunotherapy, the nature and features of surgical intervention, anesthesia, artificial blood circulation, and other peculiarities, patients are prone to infectious complications caused by conditionally-pathogenic bacteria [1,2]. In recent years, the group of aerobic, non-fermentable, gram-negative bacteria characterized by resistance to antibiotics and other prophylactic drugs has acquired partly great clinical significance [3]. The frequency of their detection in the material of patients with purulent-septic processes in the material in the data of various authors ranged from 5 to $30 \%$ [4].

Acinetobacter-like bacteria are among the most common pathogens of the family of gram-negative intestinal bacteria [5].

When developing diagnostic schemes for differentiation of non-fermented Gram-negative bacteria of different species and groups, preference is given to tests that are more accessible to practical laboratories and have a taxonomic value. One of them is the property to produce acid from glucose cytochrome oxidase under aerobic and anaerobic conditions. Determination of lysis activities of cytochromoxidases and sugars in combination with the study of cultural and morphological properties allows us to pre-differentiate Acinetobacter from other non-fermentable bacteria, while identification of their species poses some difficulties. Differentiation of Acinetobacter strains is of great importance because these triggers are more likely to cause diseases such as septic shock, various purulent-inflammatory processes associated with the low efficacy of antibiotic therapy, and its untimely use [6]. It should be noted that bacteria of the genus Acinetobacter are characterized by high antibiotic resistance [7].

Intensive and not always justified use of antibiotics for therapeutic and prophylactic purposes, which promotes the formation of polyresistant microorganisms, their spread in the clinic, unfavorable changes in the structure of the hospital microflora - is one of the reasons for the unchanged frequency of infections within hospitals. Decreased susceptibility to antibiotics of the gastrointestinal tract, respiratory tract and skin microflora in the microbial biocenosis

\footnotetext{
* Corresponding author: Davitashvili Magda

Iakob Gogebashvili Telavi State University, 1, Kartuli Universiteti str., Telavi, 2200, Georgia.
} 
disrupts the relationship between individual species of microorganisms and the possibility of more intensive reproduction is given to gram-negative conditionally pathogenic bacteria which usually have natural resistance to a number of antibiotics [8].

The study of the identification and resistance to antibiotics of Acinetobacter strains is undoubtedly of practical interest. The aim of the work was to study the biochemical properties of collectible and clinical strains of Acinetobacter by traditional methods and examining susceptibility of these strains to antibiotics.

\section{Material and methods}

The objects of study were collectible cultures of Acinetobacter calcoacetius (strain 5593), Acinetobacter lwoffi (strain 5581), obtained from the collection of the G. Eliava Institute of Bacteriophage, Microbiology and Virology, as well as clinical strains isolated from patients in Telavi.

We studied their movement, the character of growth under different conditions of cultivation in simple and complex food areas. Using traditional methods, the presence of cytochrome oxidases, catalase were determined, production of indole and hydrogen sulfide was examined, the ability (property) to reduce nitrates to nitrites was studied as well as gelatin cleavage, urease production, utilization of citrate and sodium acetate (on Simmons citrate agar). The lysis activity of sugars was studied by adding $1 \%$ of carbohydrates (glucose, maltose, sucrose, lactose, arabinose, xylose, galactose, ramnose, fructose, mannitol, mannose) to the Hugh-leifson agar. Antibiotic susceptibility was studied by the paper disc method (oriented) and double serial dilutions (minimum inhibitory concentration - MDC) [9, 10, 11 12].

\section{Results and discussion}

To identify the cultural and biochemical properties of Acienetobacter, studies were conducted to identify the species of Acienetobacter. Both biochemical variants of A. calcoaceticus were formed on solid nutrient soils (blood and fleshpeptide agar, as well as in the Endo agar).

Table 1 Cultural and biochemical properties of non-fermentable species of bacteria belonging to the genus Acinetobacter

\begin{tabular}{|l|l|l|}
\hline \multirow{2}{*}{ Biochemical properties } & \multicolumn{2}{|c|}{ Acinetobacter } \\
\cline { 2 - 3 } & anitratus & lwoffi \\
\hline Hemolysis & 0 & 0 \\
\hline Oxidase & 0 & 0 \\
\hline Pigment formation & 0 & 0 \\
\hline Movement & 0 & 0 \\
\hline Growth on MacConkey's Agar at $42^{\circ} \mathrm{C}$ & 100 & 100 \\
\hline Oxidation & \multicolumn{2}{|l}{} \\
\hline Glucose & 100 & 0 \\
\hline $10 \%$ of lactose & 100 & 0 \\
\hline Maltose & 4 & 0 \\
\hline Xylose & 68 & 0 \\
\hline Galactose & 86 & 0 \\
\hline Production & \multicolumn{2}{|l}{} \\
\hline $\mathrm{H}_{2} \mathrm{~S}$ & 0 & 0 \\
\hline Indole & 0 & 0 \\
\hline Nitrate reductase & 68 & 3 \\
\hline Gelatin & 6 & 5 \\
\hline Ureaze & 40 & 21 \\
\hline Arginine decarboxylase & 0 & 0 \\
\hline Arginine dihydrolase & 0 & 3 \\
\hline
\end{tabular}




\begin{tabular}{|l|l|l|}
\hline Catalase & 100 & 100 \\
\hline Citrate utilization & 100 & 60 \\
\hline Total number of cultures & 55 & 25 \\
\hline
\end{tabular}

We obtained round colonies with straight edges, sometimes without oily consistency, without hemolysis. For identification of Acienetobacter calcoaceticus var. Anitratus, A. calcoaceticus var. Iwoffi 5 main signs were selected: presence of pigment formation, oxidases, movement, ability to oxidize glucose. $100 \%$ of the cultures of Acinetobacter were identical to each other. They are coccobacilli, predominantly a pair of seedless, capsule-free. All cultures were oxidase negative and non-pigmented. The ability to oxidize glucose depended on the biochemical variant: $100 \%$ of the culture of A. calcoaceticus var. anitratus oxidized glucose (as opposed to A. calcoaceticus var. Iwoffi).

Division within the species also revealed $100 \%$ ability of $A$. anitratus strains to oxidize $10 \%$ concentration of lactose, xylose and galactose, whereas $A$. lwoffi did not possess this ability. $100 \%$ of the culture of $A$. anitratus and $60 \%$ of $A$. lwoffi were disposed of citrate (Table 1).

By defining additional signs for more detailed characterization and differentiation of the species, it was revealed that all cultures of Acinetobacter were catalytic, had the ability to grow at $42^{\circ} \mathrm{C}$, did not produce indole, hydrogen sulfide. Cultures were grown in the MacConkey's Agar. Less similar results were obtained while examining the ability to reduce nitrates, the hydrolysis of urea and gelatin. Some cultures of $A$. lwoffi had arginine + dihydrolase in contrast to the standard cultures.

Table 2 Resistance of A. calcoaceticus strains to antibiotics

\begin{tabular}{|c|c|c|c|}
\hline \multirow[t]{2}{*}{ № } & \multirow[t]{2}{*}{ Antibiotics } & \multicolumn{2}{|c|}{ Number of resistant strains in\% } \\
\hline & & $\begin{array}{l}\text { A. calcoaceticus } \\
\text { var. anitratus }\end{array}$ & $\begin{array}{l}\text { A. calcoaceticus } \\
\text { var. lwoffi }\end{array}$ \\
\hline 1 & Methicillin & 100 & 100 \\
\hline 2 & Oxacillin & 100 & 100 \\
\hline 3 & Ampicillin & 100 & 100 \\
\hline 4 & Carbenicillin & 100 & 100 \\
\hline 5 & Erythromycin & 100 & 100 \\
\hline 6 & Oliandomycin & 100 & 100 \\
\hline 7 & Lincomycin & 100 & 100 \\
\hline 8 & Tetracycline & 100 & 100 \\
\hline 9 & Rondomycin & 100 & 100 \\
\hline 10 & Streptomycin & 100 & 100 \\
\hline 11 & Monomycin & 34 & 88 \\
\hline 12 & Kanamycin & 45 & 72 \\
\hline 13 & Neomycin & 34 & 88 \\
\hline 14 & Gentamicin & 72 & 68 \\
\hline 15 & Polymyxin & 38 & 40 \\
\hline 16 & Chloramphenicol & 100 & 100 \\
\hline 17 & Ristomycin & 100 & 100 \\
\hline 18 & Claforan & 12 & 12 \\
\hline 19 & Fortum & 0 & 0 \\
\hline 20 & Kefzol & 100 & 100 \\
\hline & Strain number & 55 & 25 \\
\hline
\end{tabular}


In addition to differentiating Acinetobacter strains, we identified susceptibility to 20 antibiotics of $A$. calcoaceticus cultures isolated from patients in Telavi. Multiple resistance has been identified even with more active drugs such as gentamicin, polymyxin, carbenicillin. In the study of antibiotic susceptibility by the disc method, low activity of claforan and fortum was noted (Table 2).

Determination of antimicrobial activity in relation to A. calcoaceticus by MCD method carbenicillin, kanamycin, claforan, fortum comparison of the obtained data showed that the lowest activity against these microorganisms had carbenicillin and the largest - fortum.

Claforan was characterized by a favorable rate in the antibiotic study group. In $60.8 \%$ of claforan MDC strains ranged from $20-80 \mu \mathrm{g} / \mathrm{ml}$, in $32.3 \%$ of the above strains growth was inhibited at the $200-400 \mu \mathrm{g} / \mathrm{ml} \mathrm{level} \mathrm{(Table} 3$ ).

Table 3 Distribution by degree of sensitivity (MCD) of 25 clinical strains of Acinetobacter calcoaceticus

\begin{tabular}{|l|l|l|l|l|l|l|l|l|}
\hline \multirow{2}{*}{ № } & \multirow{2}{*}{ Antibiotics } & \multicolumn{7}{|c|}{ MDC mcg / ml } \\
\cline { 3 - 9 } & & $\mathbf{1 - 1 0}$ & $\mathbf{2 0}$ & $\mathbf{4 0}$ & $\mathbf{7 0 - 8 0}$ & $\mathbf{1 0 0}$ & $\mathbf{2 0 0}$ & $\mathbf{4 0 0}$ \\
\hline 1 & Kanamycin & 0 & 0 & 0 & 0 & 0 & 0 & 25 \\
\hline 2 & Claforan & 0 & 3 & 3 & 6 & 0 & 1 & 7 \\
\hline 3 & Fortum & 20 & 5 & 0 & 0 & 0 & 0 & 0 \\
\hline 4 & Carbenicillin & 0 & 0 & 0 & 1 & 3 & 1 & 20 \\
\hline
\end{tabular}

\section{Conclusion}

Thus, based on the obtained data, it was able to determine species belonging to A. calacoaceticus var. anitratus, A. calcoaceticus var. lwoffi. Acinetpbacter strains are characterized by high resistance to many antibiotics, which are more commonly used to treat infectious diseases caused by these non-fermenting microorganisms.

\section{Compliance with ethical standards}

\section{Acknowledgments}

I am grateful to the Rector and Administrator, Iakob Gogebashvili Telavi State University, to the Department of Natural Sciences and Information Technologies for their support.

\section{Disclosure of conflict of interest}

There is no conflict of interest amongst the authors.

\section{References}

[1] Mahon, Connie R; Manuselis, George. Textbook of Diagnostic Microbiology, 2nd edition. Saunders. 2000.

[2] Baran EJ, Peterson LR, Finegold SM: Bailey \& Scott's. Diagnostic Microbiology. 9th edn. St. Louis: Mosby-Year Book Inc., 1994; p. 400.

[3] Williams, J D, Geddes, A M Pharmacology of Antibiotics. Springer US. Plenum Press, New York. 1976.

[4] José-Luis Capelo-Martínez, Gilberto Igrejas. Antibiotic Drug Resistance. John Wiley \& Sons, Inc. 2020.

[5] P Rani, MB Latha, SG Reddy, AK Bilolikar. A study of Acinetobacter from various clinical specimens and its antibiotic sensitivity pattern in a tertiary care hospital. J Med Sci Res. 2015.

[6] Katerina Kon, Mahendra Rai. Antibiotic Resistance. Mechanisms and New Antimicrobial Approaches. 1st Edition. Academic Press. 2016.

[7] T Karsligil, I Balci, and Y Zer. Antibacterial Sensitivity of Acinetobacter Strains Isolated from Nosocomial Infections. The Journal of International Medical Research. 2004; 32:436 - 441. 
[8] Richard J Fair, Yitzhak Tor. Antibiotics and Bacterial Resistance in the 21st Century. Perspectives in Medicinal Chemistry. 2014; 6:25-64.

[9] Bauer, JD, Ackermann PG, Toro G: Clinical Laboratory Methods: Methods in Microbiology. St. Louis: CV Mosby Co. 1974; p. 689.

[10] Gillespie, S H, Hawkey, P M Principles and Practice of Clinical Bacteriology. Second Edition. England. John Wiley \& Sons Ltd. 2006.

[11] Harley, J Laboratory Exercises in Microbiology. 10th edition. McGraw-Hill Publishing. 2017.

[12] Toth EM, Borsodi AK, Felfoldi T, Vajna B, Sipos R and Marialigeti K Practical Microbiology. Eotvos Lorand University. 